\title{
Ages of Big Sagebrush Following Brush Control
}

JAMES W. BARTOLOME and HAROLD F. HEADY

Highlight: Six stands of big sagebrush, which had been plowed or sprayed earlier to remove brush and enhance understory vegetation, were sampled in southeastern Oregon to determine age structure of the shrubs and to evaluate rates of reinvasion. Five of the six stands contained big sagebrush older than the treatment. In three project areas plants established the first year following treatment formed the largest age class, 12 to $24 \%$ of the stand, indicating that reinvasion begins immediately after treatment. Most reestablishment occurred in the first several years after treatment for all locations. Establishment occurred either from seeds present in the soil at the time of treatment or from seeds produced as the plants became established and seed bearing. Treated sagebrush/grass ranges should remain highly productive under proper grazing use despite reinvasion of big sagebrush.

This report describes the age structure of big sagebrush (Artemisia tridentata) in areas of brush control and seeding of crested wheatgrass (Agropyron cristatum and A. desertorum). Age structure of stands has application to the status of vegetation modification, with particular relevance to the projected lifespan of the treatment, effectiveness of the treatment, and plans for future management.

The location of this study, the Vale District of the Bureau of Land Management (BLM) in southeastern Oregon, was the subject of a large scale rangeland rehabilitation program extensively evaluated elsewhere (Heady and Bartolome 1977). The BLM spent about 10 million dollars on the Vale District to reduce stands of big sagebrush, either to permit seeding of exotic forage species or to enhance the growth of native understory plants, mainly bluebunch wheatgrass (Agropyron spicatum). The primary goals were to halt soil erosion and to stabilize the local livestock industry through increased grazing capacity.

Eighty-eight percent of the Vale District is dominated by big sagebrush, and vegetation of the remainder has a strong shrub component. This vast area of sagebrush/grass is characterized by complex, intergrading mixtures of several dominant shrub and grass species depending upon prior treatment and varying microsite. Excellent condition range may contain up to $25 \%$ sagebrush and $75 \%$ grass cover. The mix of bunchgrasses and sagebrush at the start of the Vale Program had been changed toward high brush density, often greater than $50 \%$ cover, and few palatable bunchgrasses as a result of a century of exploitive grazing. In some locations a perennial grass understory was almost absent, with annuals or bare soil between the shrubs.

\footnotetext{
The authors are lecturer and associate specialist and professor, respectively, Department of Forestry and Resource Management, University of California, Berkeley 94720.

The assistance of the Bureau of Land Management, Oregon State and Vale District Offices, and the U.S. Forest Service, Pacific Northwest Forest and Range Experiment Station, is gratefully acknowledged.

Ron Wakimoto. Lin Yeilding, and Jesse Theuri contributed to the study.

Manuscript received September 3, 1977.
}

\section{Literature}

Understanding of the effects of range improvement primarily depends upon quantification of the ecological processes involved in productivity. Much published work has reported on aspects of vegetation change, ecosystem processes, and management of sagebrush-grass range. Papers cited emphasize big sagebrush changes following control.

Sagebrush eventually reinvades where it has been controlled in most instances. The rate of invasion is related to initial success of shrub control (Weldon et al. 1958), initial condition of the range (Hedrick et al. 1966), and success of seeding (Robertson et al. 1966; Frischknecht and Bleak 1957). Yet reestablishment is often highly localized (Hironaka and Tisdale 1963) and concentrated in certain, perhaps wet, years (Frischknecht and Harris 1968). Heavy grazing speeds the rate of reinvasion (Johnson 1969); yet big sagebrush reinvades in some years even without grazing (Frischknecht and Harris 1968).

Different subspecies of Artemesia tridentata may behave differently. The unpalatable subspecies $A$. tridentata tridentata may be the most aggressive (McDonough and Harniss 1975). Differences between subspecies Artemesia tridentata vaseyana and $A$. tridentata tridentata may have led to several conflicting results in rate of reinvasion. Additional confusion on reinvasion rates stems from the apparent lack of correlation between size and age in immature Artemesia tridentata tridentata (Beetle 1960; Daubenmire 1975). Some authors used size classes as estimates for age of plants. The long delay before reinvasion reported by Harniss and Murray (1973) could also lead to inaccurate conclusions concerning reinvasion of brush.

Economists have generally regarded chemical control of sagebrush as having a finite life span, usually less than 20 years (e.g., Kearl and Branham 1967). They project a finite life span based on the comparison of adjacent treated and untreated areas, where the difference disappears in between 10 to 20 years. This comparison would be clouded by additional improvement of both treated and untreated ranges. Kearl (1965) found that more than $50 \%$ of respondents to a survey of individuals using herbicides to control big sagebrush between 1952 and 1964 did not plan ever to respray. Seedings following mechanical control are also generally regarded as finite in life span, usually 20 years (e.g., Caton and Beringer 1960), perhaps with even less justification than for brush control alone. One would hope that proper management of rehabilitated big sagebrush-grass would not result in deteriorated stands after 20 years.

The economics of large scale brush control and seeding operations have yet to be adequately developed. On the Vale District the initial efforts by Stevens and Godfrey (1976) and Nielson, et al. (1966) have not adequately addressed problems associated with the quantification of interactive effects of a wide spectrum of range-improvement practices. Benefits are not 
confined to treated areas alone. Adjacent untreated range improved at least as spectacularly as the treated range on the Vale District (Heady and Bartolome 1977), a result which must be included as a benefit. Economic evaluation therefore needs to consider the district or ranch as a whole.

\section{Methods}

Methods of vegetation sampling used in this study provide information on the life expectance of range improvement treatments instigated by the Vale Program.

In June 1976, 50 sagebrush plants were collected in each of six project areas to determine age through ring counts, density on the ground, and size of plants. All big sagebrush plants within a randomly located $1 \mathrm{~m}$ wide belt were measured for crown diameter and height and cut at ground level for ring counts to estimate age. The sampling ended when 50 plants had been collected. Density then was determined from the length of the transect. Ferguson (1964) discusses ring-dating in detail for big sagebrush. Although rotten centers and incomplete rings reduced the accuracy of age determination, the number of annual rings in any stem younger than approximately 20 years gave a reasonably clear estimate of the age of the plant. Estimates of actual age were not possible with 29 brush plants, or about $10 \%$ of the samples, due to missing centers.

Six project areas within the Vale District constituted the study areas. Five wcrc plowed prior to seeding (Table 1), while one was sprayed with 2,4-D to kill brush. All areas are currently grazed by cattle. The oldest treatment is 24 years old, the most recent 9 years. No obvious differences relating only to age of treatment were noted.

\section{Results and Discussion}

An apparent total initial control of brush resulted in the Ten-Mile seeding project because it was the only project area which did not contain sagebrush plants older than the treatment (Fig. 1). The most abundant age class represented those plants which established in the first year following treatment. However, sagebrush plants continued to establish during later years following treatment. No plants younger than 4 years old were found. An interesting aspect of the age structure of the big sagebrush population in this project area is an apparent second period of establishment five years following the initial period of establishment. This second peak could be due to seedlings established as the first group of plants became old enough to produce seed or an exceedingly favorable year for establishment. The structure of the stand suggests an effective control, completely eliminating the brush, but a rapid and continued reinvasion in the years following treatment.
The four other plowed and seeded areas (Antelope, Brickey Springs, Big Ridge, and Rock Creek) displayed similar patterns of population structure (Fig. 1). A few plants apparently survived the initial plowing. Reestablishment of the brush then proceeded rapidly in the years following treatment. The first year following treatment was the largest age class in the Big Ridge and Antelope project areas. Establishments of sagebrush rapidly declined in successive years following treatment. Establishment was more continuous with a later peak in the Rock Creek and Brickey Springs projects.

Brush control was very poor in the Basque spray and seed project. Many of the shrubs were more than 25 years old (Fig. 1). However, the pattern of reinvasion following treatment is similar to the more effective plow treatments. Density of sagebrush in the Basque spray was less than for the more iffectively controlled area of Rock Creek, where few of the shrubs survived treatment (Table 1). Reinvasion of sagebrush is apparently not significantly related to the degree of brush kill for these areas.

A common assertion is that big sagebrush invades rapidly following land treatment and that most seedlings become established at that time. In part, the results of the age-class survey substantiate that claim. On three of the treated areas the most numerous age class occurred the year following treatment. However, all treated areas showed evidence of continued establishment for several years following treatment, except that the Antelope and Brickey Springs seedings had no plants younger than 6 years (Fig. 1).

Only the Ten-Mile seedings displayed complete control of $\mathrm{bi}_{\text {s }}$ sagebrush by the initial treatment; in all other projects sampled, ample big sagebrush plants remained after treatment to allow reinvasion from seed produced. Invasion was by establishment of seedlings immediately after treatment from seed on the site and from seed produced later. No evidence was found that particular years were more favorable for sagebrush establishment than others. Individual areas showed groups or cohorts of seedlings but they were of different ages. From 1970 onward few big sagebrush plants became established.

Size and age of plant were poorly correlated. Although correlation coefficients for age (number of annual rings) and size (height times square of diameter) of plant were statistically significant for five of the six areas, coefficients were low and of little use for predicting age (Table 1). The Big Ridge seeding showed a correlation of 0.130 or no relation at all between size and age. Interestingly, the Big Ridge seeding consisted primarily of the subspecies Artemesia tridentata tridentata Nutt.

Table 1. Age in years and density of big sagebrush on six treated areas in 1976.

\begin{tabular}{|c|c|c|c|c|c|c|c|c|c|}
\hline \multirow[b]{2}{*}{ Project name } & \multirow{2}{*}{$\begin{array}{l}\text { Brush control } \\
\text { method }\end{array}$} & \multirow{2}{*}{$\begin{array}{l}\text { Primary big } \\
\text { sagebrush } \\
\text { subspecies }^{1}\end{array}$} & \multirow{2}{*}{$\begin{array}{l}\text { Age of } \\
\text { treatment } \\
\text { (years) }\end{array}$} & \multicolumn{4}{|c|}{$\begin{array}{c}\text { Age (years) } \\
\text { of big sagebrush }\end{array}$} & \multirow{2}{*}{$\begin{array}{c}\text { Density of } \\
\text { big sage- } \\
\text { brush } \\
\text { (plants } / \mathrm{m}^{2} \text { ) }\end{array}$} & \multirow{2}{*}{$\begin{array}{l}\text { Correlation } \\
\text { between size } \\
\text { and age } \\
\text { "r" }{ }_{2}\end{array}$} \\
\hline & & & & Mean & Median & Minimum & Maximum & & \\
\hline $\begin{array}{l}\text { Ten-Mile Seeding } \\
\text { Brickey Springs }\end{array}$ & plow & wyomingensis & 24 & 17.7 & 19 & 5 & 24 & 0.29 & $0.348^{*}$ \\
\hline Seeding & plow & wyomingensis & 15 & 12.6 & 13 & 6 & 21 & 0.20 & $0.448 * *$ \\
\hline Rock Creek Seeding & plow & wyomingensis & 15 & 12.2 & 12 & 5 & $26+$ & 0.53 & $0.427^{* *}$ \\
\hline Big Ridge Seeding & plow & tridentata & 10 & 9.3 & 10 & 1 & 18 & 0.20 & 0.130 \\
\hline Antelope Seeding & plow & wyomingensis & 10 & 11.2 & 10 & 7 & 23 & 0.27 & $0.457 * *$ \\
\hline Basque Brush Control & spray & wyomingensis & 9 & 15.4 & 11 & 3 & $38+$ & 0.45 & $0.486^{* *}$ \\
\hline
\end{tabular}

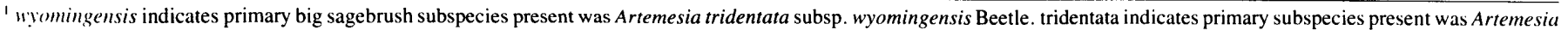
trick'ntata subsp. tridentata Nutt.

and denote significant correlation between size and age at the .05 and .01 levels, respectively.
} 

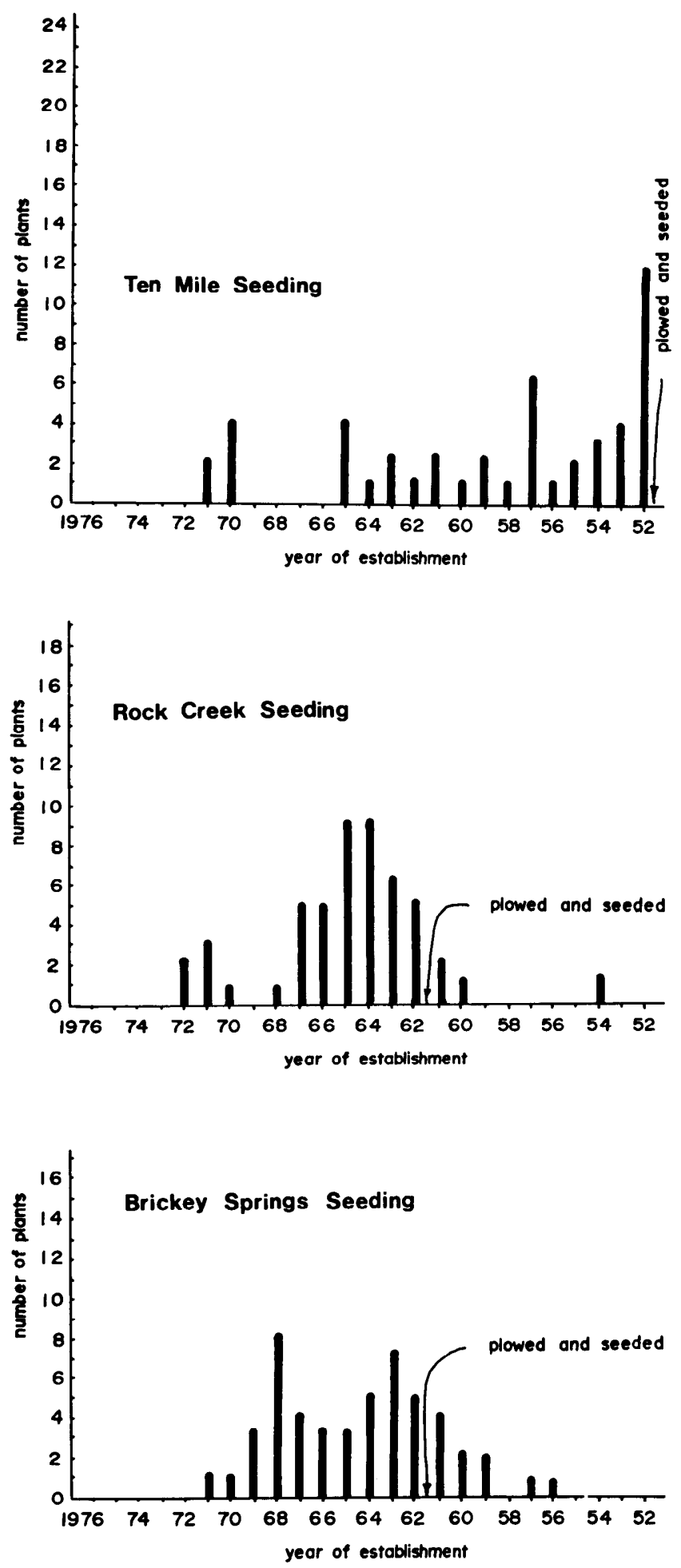
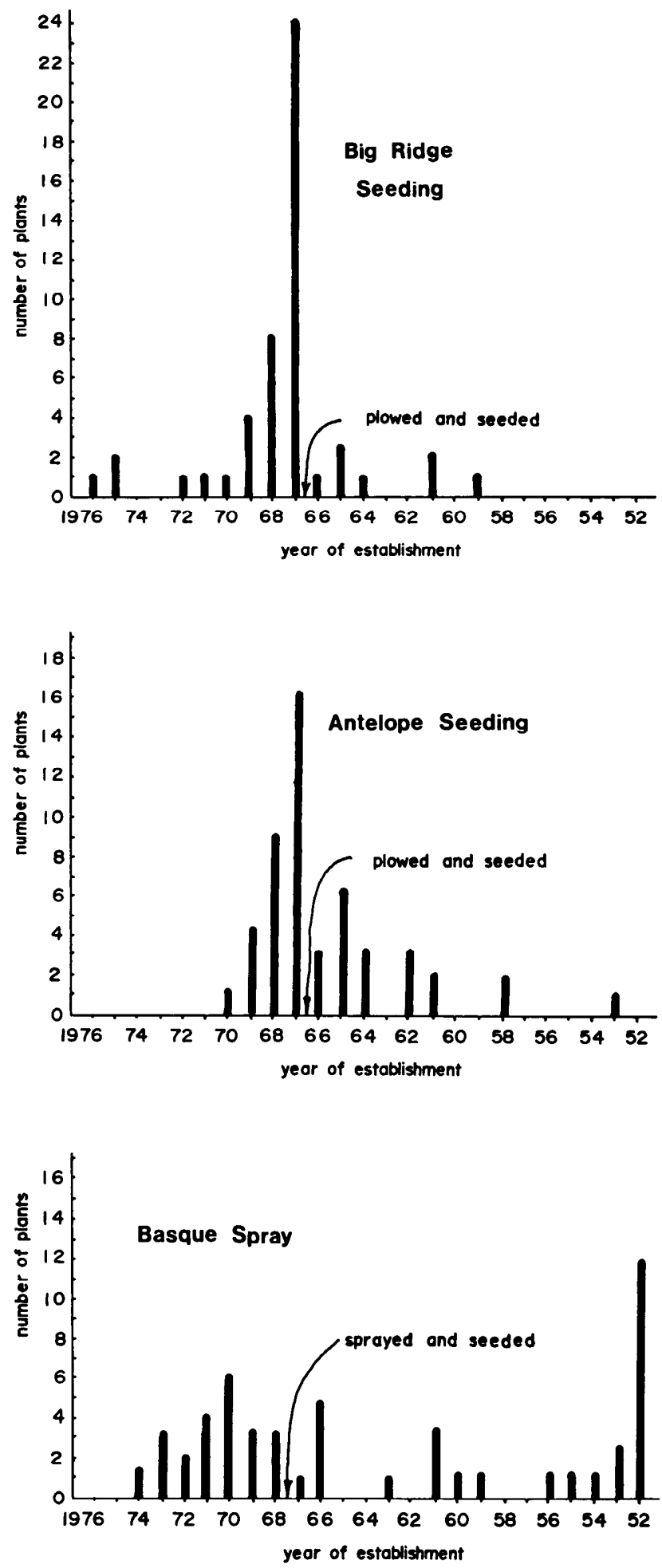

Fig. 1. Apparent year of establishment of big sagebrush plants within six treated areas as determined through ring counts. Bars represent the number of plants established in each year out of 50 sampled.

while the others were primarily $A$. tridentata wyomingensis Beetle, as classified using the criteria of Winward and Tisdale (1977). The practice of making inferences about age class distribution of sagebrush stands based on size classes is highly inaccurate and in fact may lead to erroneous conclusions. Apparent seedlings less than $1 \mathrm{dm}(5 \mathrm{in})$ tall may be more than 10 years old.

Benefits of treatment during the Vale Program should last indefinitely under the present proper management. This premise is based on several facts and assumptions. Stands of grass appear to have deteriorated in the first few years following treatment, but most of the apparent reinvasion of big sagebrush is actually the recovery of unkilled plants and the growth of seedlings established in the first few years following treatment. Seedlings established later than the first year following treatment generally remained small, and many did not reach 
maturity. Old brush control projects did not show more sagebrush reinvasion than recent projects, and on several sites continued reinvasion of big sagebrush appeared to be completely halted after the early reestablishment following treatment and before the thickening of the grass stand. Areas with nearly complete big sagebrush kills showed invasion with densities not ultimately different from less effectively controlled areas.

An often misconstrued aspect of vegetation change in sagebrush/grass range is that since depleted sagebrush/grass ranges contain mostly sagebrush, perhaps with a large quantity of cheatgrass (Bromus tectorum), sagebrush reinvasion will bring deterioration of the perennial grass cover. We reject this negative correlation between sagebrush density and grass productivity on well-managed ranges. Sagebrush/grass ranges may contain a high proportion of big sagebrush before grass production will be significantly decreased. The key to proper management is maintenance of a balance between vigorous stands of perennial grasses and big sagebrush. Judiciously used brush control practices, seeding, and proper grazing can maintain this balance.

\section{Literature Cited}

Beetle, A.A. 1960. A study of sagebrush. Wyoming Agr. Exp. Sta. Bull. 368. 83p.

Caton, D.D., and C. Beringer. 1960. Cost and benefits of reseeding rangelands in southern Idaho. Idaho Agr. Exp. Sta. Bull. 326. 31p.

Caton, D.D., and C. Beringer. 1975. Ecology of Artemesia tridentata subsp. tridentata in the State of Washington. Northwest Sci. 49:24-35.

Ferguson, C.W. 1964. Annual rings in big sagebrush, Artemesia tridentata. Univ. Arizona Press Papers of Lab. of Tree-ring Res. No. 1. 95p.
Frischknecht, N.C., and A.T. Bleak. 1957. Encroachment of big sagebrush on seeded range in northeastern Nevada. J. Range Manage. 10:165-170.

Frischknecht, N.C., and L.E. Harris. 1968. Grazing intensities and systems on crested wheatgrass in central Utah: response of vegetation and cattle. U.S. Dep. Agr. Tech. Bull. 1388. 47p.

Harniss, R.O., and R.B. Murray. 1973. Thirty years of vegetal change following burning of sagebrush-grass range. J. Range Manage. 26:322-325.

Heady, H.F., and J.W. Bartolome. 1977. The vale rangeland rehabilitation program: the desert repaired in southeastern Oregon. U.S. Forest Serv. Resour. Bull. PNW-70. 138p.

Hedrick, D.W., D.H. Hyder, F.A. Sneva, and C.E. Poulton. 1966. Ecological response of sagebrush-grass in central Oregon to mechanical and chemical removal of Artemesia. Ecology 47:432-439.

Hironaka, M., and E.W. Tisdale. 1963. Secondary succession in annual vegetation in southern Idaho. Ecology 44:810-812.

Johnson, W.M. 1969. Life expectancy of a sagebrush control in central Wyoming. J. Range Manage. 22:177-182.

Kearl, W.G. 1965. A survey of big sagebrush control in Wyoming, 1952-1964. Wyoming Agr. Exp. Sta. Mimeo. Circ. 217. 42p.

Kearl, W.G., and M. Brannan. 1967. Economics of mechanical control of sagebrush in Wyoming. Wyoming Agr. Exp. Sta. Sci. Monogr. 5. 35p.

McDonough, W.T., and R.O. Harniss. 1975. Know your sagebrush-and better your range. Utah Sci. Sept., 1975. 99-103.

Nielson, D.B., W.G. Brown, D.H. Gates, and T.R. Bunch. 1966. Economics of federal range use and improvement for livestock production. Oregon Agr. Exp. Sta. Bull. 92. 40p.

Robertson, J.H., R.E. Eckert, and A.T. Bleak. 1966. Responses of grasses seeded in an Artemesia tridentata habitat in Nevada. Ecology 47:187-194.

Stevens, J.B., and E.B. Godfrey. 1976. Use rates, resource flows and efficiency of public investment in range improvements. Amer. J. Agr. Econ. Nov, 1972. 611-621.

Weldon, L.W., D.W. Bohmont, and H.P. Alley. 1958. Reestablishment of sagebrush following chemical control. Weeds 6:298-303.

Winward, A.H., and E.W. Tisdale. 1977. Taxonomy of the Artemesia tridentata complex in Idaho. Univ. Idaho, College of Forestry, Wildl., and Range Sci. Bull. No. 19. 15p. 